\title{
Production of lignocellulolytic enzymes by Aspergillus niger biofilms at variable water activities
}

\author{
Gretty K. Villena \\ Laboratorio de Micología y Biotecnología \\ Universidad Nacional Agraria La Molina \\ Apartado 456 Lima 1, Perú \\ Tel: 5113495647 Ext. 863 \\ Fax: 5113495670 \\ E-mail: gkvch@lamolina.edu.pe \\ Marcel Gutiérrez-Correa* \\ Laboratorio de Micología y Biotecnología \\ Universidad Nacional Agraria La Molina \\ Apartado 456 Lima 1, Perú \\ Tel: 5113495647 Ext. 863 \\ Fax: 5113495670 \\ E-mail:mgclmb@lamolina.edu.pe
}

\begin{abstract}
Financial support: This work was partially supported by INCAGRO (Ministry of Agriculture, Perú) and CONCYTEC (Ministry of Education, Perú) and
\end{abstract} by PhD grants to G.K.V. (INCAGRO and CONCYTEC).

Keywords: biofilm, cellulase, ethylene glycol, water activity, xylanase.

$\begin{array}{ll}\text { Abbreviations: } & \mathrm{a}_{\mathrm{w}} \text { : water activity } \\ \text { BF: biofilm fermentation } \\ \text { ENG: endoglucanase } \\ \text { FPA: filter paper activity } \\ \text { IU: international unit } \\ \text { SAF: surface adhesion fermentation } \\ \text { SF: submerged fermentation } \\ \text { SSF: solid state fermentation } \\ \text { XYL: xylanase }\end{array}$

Lignocellulolytic enzyme production by Aspergillus niger was compared both in submerged fermentation (SF) and biofilm fermentation (BF) at varying water activities. Maximal filter paper activity, endoglucanase and xylanase activities were much higher in BF (2.96, 4.7 and 4.61 $\mathrm{IU} \mathrm{ml}^{-1}$, respectively) than in SF cultures (1.71, 1.31 and $2.3 \mathrm{IU} \mathrm{ml}^{-1}$, respectively) but biomass yields were lower in BF than in SF $\left(0.338 \mathrm{~g} \mathrm{~g}^{-1}\right.$ and 0.431 $\mathrm{g}^{-1}$, respectively). In the presence of $20 \%$ ethylene glycol $\left(a_{w}=0.942\right)$ the enzyme activities decreased in both systems but BF still had higher levels (1.0, 1.0 and 2.6 IU ml $\mathrm{I}^{-1}$, respectively) than $\mathrm{SF}$ cultures $(0.6,0.7$ and $1.5 \mathrm{IU} \mathrm{ml}^{-1}$, respectively). An increase in xylanase specific activity of more than 2 fold (from 4.2 to 10.2 IU $\mathrm{mg}^{-1}$ biomass) was observed in the presence of $20 \%$ ethylene glycol, suggesting differential regulatory mechanisms in biofilm fermentation related to cell adhesion.

Cellulases are increasingly used by several industries including fruit processing, feed production, textiles and others (Bhat, 2000; Kirk et al. 2002). Cellulases and most industrial enzymes are produced by submerged fermentation (SF) but solid state fermentation (SSF) is used to a lesser extent. The main advantages of SSF are low technology and high volumetric productivity, thus reduced downstream processing costs (Hölker et al. 2004). For a long time it has been thought that the main advantages of SSF are due to water limitation of the system so that a higher product concentration is attained. An additional but less investigated advantage of SSF may be enhanced physiological processes in cell adhesion or biofilm formation that is characteristic for SSF.

Biofilm processes are used mainly for waste water treatment but they are also considered for metabolite and enzyme production (Freeman and Lilly, 1998; Fiedurek 2001; Iqbal and Saeed, 2005; Wu et al. 2005; Yang et al. 2005; Skowronek and Fiedurek, 2006). Although fungal biofilms are less known than bacterial biofilms, they can be used for cellulase production as it has been recently showed (Villena et al. 2001).

*Corresponding author 


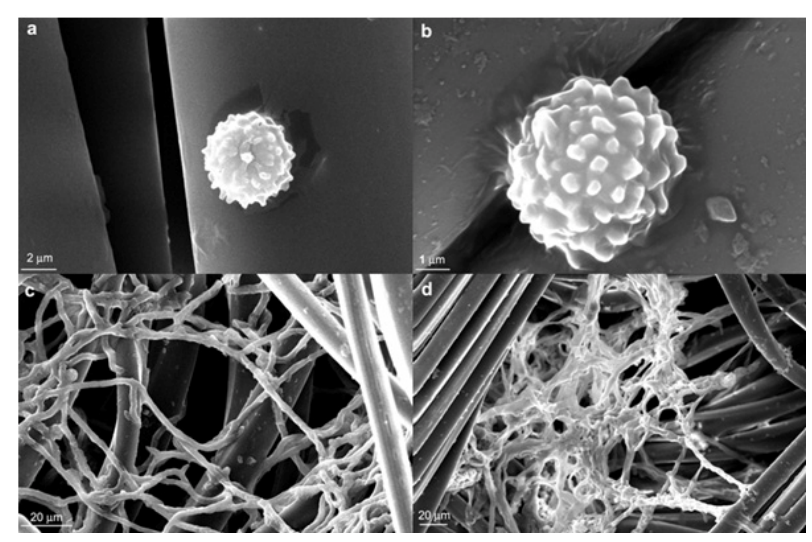

Figure 1. Cryo-scanning electron micrographs of Aspergillus niger spore adhesion and biofilm development on polyester cloth at $0 \%, a_{w}=0.976(a, c)$ and $20 \%$ ethylene glycol, $\mathrm{a}_{\mathrm{w}}=0.942(b, d)$.

Both SSF and biofilm fermentation (BF) depend on surface adhesion. A new fermentation category named surface adhesion fermentation (SAF) was first proposed by Gutiérrez-Correa and Villena (2003). The concept of a biofilm presumes either a population or a community of microorganisms living attached to a surface. Biofilms can be developed on either biotic or abiotic surfaces from a single species or as a community derived from several species (O'Toole et al. 2000; Fenchel, 2002). It should be noted that adhesion and subsequent differential gene expression to generate phenotypes distinct from those of free living organisms are two unifying processes of the biofilm concept (O'Toole et al. 2000; Ghigo, 2003). Filamentous fungi are naturally adapted to growth on surfaces and in these conditions they show a particular physiological behaviour which it is different to that in submerged culture; thus, they can be considered as biofilm forming organisms according to our former concept. The advantages of this form of growth have been industrially exploited by two culture systems: SSF and cell immobilization on inert surfaces.

Technology of cell immobilization was highly developed during the last two decades based on the operative advantages in the productive process instead of physiological issues (Groboillot et al. 1994). Natural adsorption on solid supports is an immobilization technique that it has been used with filamentous fungi thus neglecting its study as a way of biofilm formation. Actually, once spores are adsorbed to the support they grow attached to it thus forming a film. We prefer the term biofilm fermentation instead of cell immobilization because the microbe is an active and differential entity (GutiérrezCorrea and Villena, 2003).

The importance of the water activity $\left(\mathrm{a}_{\mathrm{w}}\right)$ in microbial physiological processes is well recognized. It is known that $\mathrm{a}_{\mathrm{w}}$ is a critical factor affecting the growth and metabolism of fungi (Kredics et al. 2000; Parra et al. 2004) and, especially in SSF it is also considered as a fundamental parameter for mass transfer (Gervais and Molin, 2003). Likewise, the production and secretion of enzymes could be affected by water activity $\left(a_{w}\right)$ and by the nature of the $a_{w}$ depressor (Acuña-Argüelles et al. 1994; Kredics et al. 2000; Gervais and Molin, 2003). Despite the importance of water activity in many enzyme production systems, its role in biofilm fermentation is not explored. This paper describes the effect of ethylene glycol as a water activity depressor on the lignocellulolytic enzyme production by Aspergillus niger biofilms.

\section{MATERIALS AND METHODS}

\section{Fungal strain and inoculum formation}

Aspergillus niger ATCC 10864 was used throughout the study and was maintained on potato dextrose agar slants. Spores were washed from 5-day agar-slant cultures with 10 $\mathrm{ml}$ of $0.1 \%(\mathrm{v} / \mathrm{v})$ Tween 80 solution, counting in a Neubauer chamber and diluted to give $1 \times 10^{6}$ spores $\mathrm{ml}^{-1}$. This suspension was used as the inoculum.

\section{Culture medium}

Duff (1988) medium was used in all experiments. The culture medium contained per liter: $2 \mathrm{~g} \mathrm{KH}_{2} \mathrm{PO}_{4} ; 1.4 \mathrm{~g}$ $\left(\mathrm{NH}_{4}\right)_{2} \mathrm{SO}_{4} ; 0.3$ g urea; $0.3 \quad \mathrm{~g} \quad \mathrm{CaCl}_{2} .2 \mathrm{H}_{2} 0 ; 0.3 \mathrm{~g}$ $\mathrm{MgSO}_{4} .7 \mathrm{H}_{2} 0 ; 1 \mathrm{~g}$ peptone; $2 \mathrm{ml}$ Tween $80 ; 5 \mathrm{mg}$ $\mathrm{FeSO}_{4} .7 \mathrm{H}_{2} \mathrm{O} ; 1.6 \mathrm{mg} \mathrm{MnSO}{ }_{4} .2 \mathrm{H}_{2} \mathrm{O} ; 1.4 \mathrm{mg} \mathrm{ZnSO}{ }_{4} .7 \mathrm{H}_{2} \mathrm{O}$; $2 \mathrm{mg} \mathrm{CoCl} 2.6 \mathrm{H}_{2} \mathrm{O}$; and $10 \mathrm{~g}$ lactose. The initial $\mathrm{pH}$ was 5.5 .

To test the effect of $a_{w}$, the same medium was used supplemented with ethylene glycol at the following final concentrations $(\% \mathrm{v} / \mathrm{v}): 5 \%, 10 \%, 15 \%$ and $20 \%$.

\section{Submerged fermentation}

$30 \mathrm{ml}$ of the culture medium in $125 \mathrm{ml}$ flasks was inoculated with $0.9 \mathrm{ml}$ spore suspension to each flask. After inoculation the flasks were incubated at $28^{\circ} \mathrm{C}$ in a shaker bath at $175 \mathrm{rpm}$.

\section{Biofilm fermentation}

Polyester cloth 100/1 (65\% denier and 35\% textured polyester with circular stitch), was used as support for biofilm formation (Villena et al. 2001). $2 \times 2 \mathrm{~cm}$ squares were thoroughly washed with distilled water and oven dried at $105^{\circ} \mathrm{C}$. Each flask containing a cloth square in $30 \mathrm{ml}$ distilled water was inoculated with $0.9 \mathrm{ml}$ spore suspension, incubated for $15 \mathrm{~min}$ at $28^{\circ} \mathrm{C}$ in a shaker bath at $175 \mathrm{rpm}$ to allow the attachment of spores. After this contact period, the squares were washed twice with distilled water under agitation at $175 \mathrm{rpm}$ for $15 \mathrm{~min}$; then they were transferred to flasks containing $30 \mathrm{ml}$ of the culture medium and incubated at $28^{\circ} \mathrm{C}$ in a shaker bath at $175 \mathrm{rpm}$ (Villena et al. 2001). Two flasks were prepared for each sampling time. 

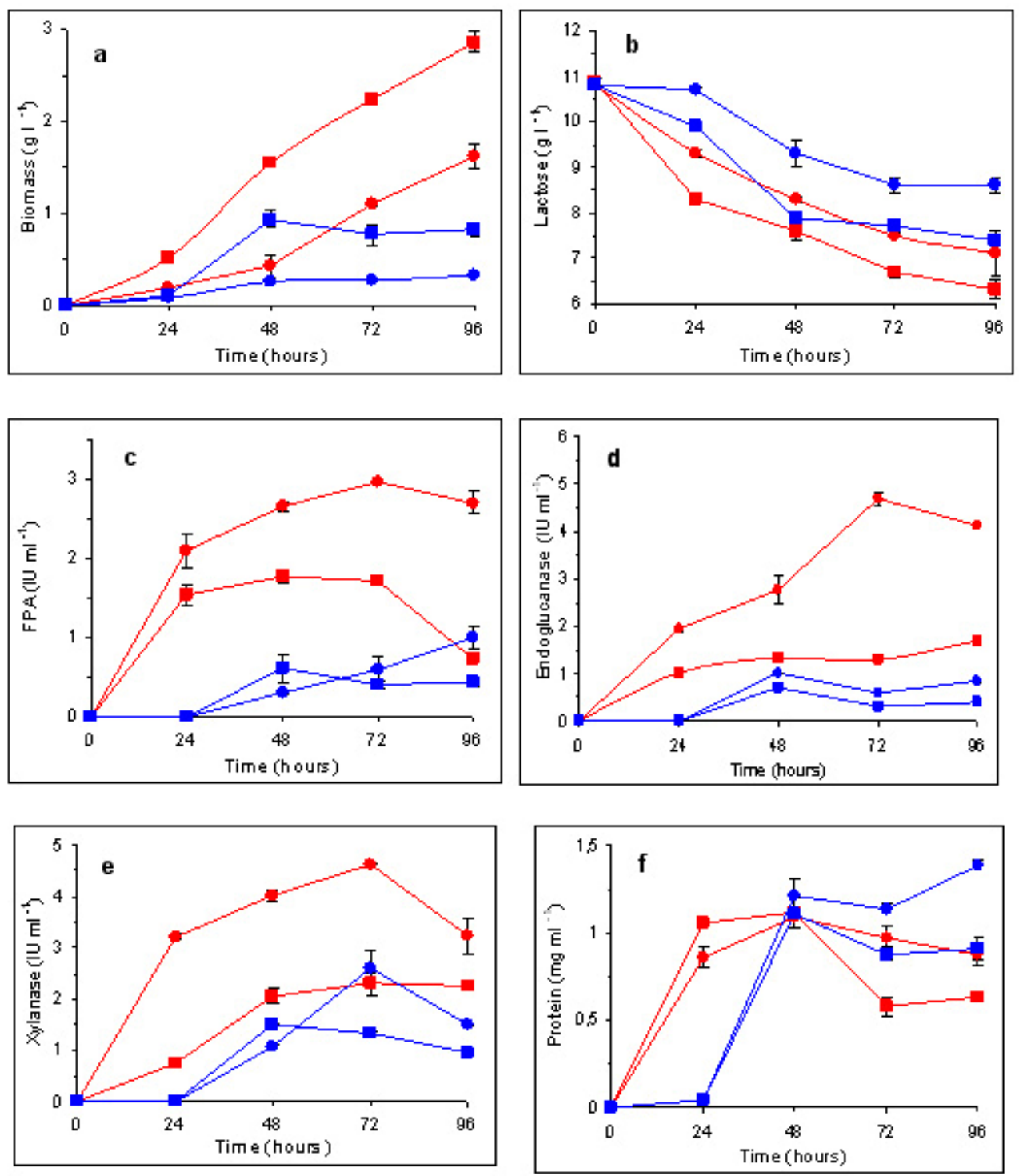

Figure 2. Time course profiles of fermentation variables of Aspergillus niger biofilm $(\bullet, \bullet)$ and freely suspended mycelial $(\square, \square)$ cultures at $0 \%$ (red symbols) and $20 \%$ ethylene glycol (blue symbols). The error bars on the graphs represent two replicate samples.

\section{Water activity determination}

Water potential for each ethylene glycol concentration in the culture medium was measured using a WESCOR HR33T Dew Point Microvoltimeter model 5103 with C-52 sample chamber. Water potential and water activity are related by $\Psi \mathrm{V}_{\mathrm{m}}=\mathrm{RT} \ln \left(\mathrm{a}_{\mathrm{w}}\right)$, where $\Psi$ is the water potential (Pa), $\mathrm{Vm}$ is the molar volume of water $\left(\mathrm{mol} \mathrm{m}^{-3}\right), \mathrm{R}=8.314$ is the gas constant $\left(\mathrm{J} \mathrm{mol}^{-1} \mathrm{~K}^{-1}\right), \mathrm{T}$ is the temperature $(\mathrm{K})$ and $\mathrm{a}_{\mathrm{w}}$ is the water activity. Under the conditions used the water activity of the cultured medium containing $0 \%, 5 \%$, $10 \%, 15 \%$ and $20 \%$ of ethylene glycol were $0.976(\Psi=$ -3.35 MPa), $0.971(\Psi=-4.05 \mathrm{MPa}), 0.964(\Psi=-5.03$ $\mathrm{MPa}), 0.954(\Psi=-6.5 \mathrm{MPa})$ and $0.942(\Psi=-8.25 \mathrm{MPa})$, respectively.

\section{Cryo-SEM}

Biofilm samples were immersed in $10 \%$ glycerol for $2 \mathrm{hrs}$ at $4^{\circ} \mathrm{C}$. Then, they were thoroughly washed with $0.05 \mathrm{M}$ phosphate buffer (pH 7.4) and frozen by plunging them into liquid nitrogen. Surface water was removed by sublimation at $-65^{\circ} \mathrm{C}$ for $10 \mathrm{~min}$ and specimens were sputter-coated with gold (Ma et al. 2005). Samples were then examined at $-80^{\circ} \mathrm{C}$ with a LEO $1420 \mathrm{PV}$ variable pressure scanning electron microscope.

\section{Assays}

Biomass from $\mathrm{BF}$ was determined by removing polyester squares from the fermentation broth at different time 
intervals, washing them three times by shaking in $30 \mathrm{ml} 50$ $\mathrm{mM}$ citrate buffer, $\mathrm{pH} 4.8$, for $10 \mathrm{~min}$ each wash at $28^{\circ} \mathrm{C}$ and $175 \mathrm{rpm}$, dried overnight and weighed. Biomass from SF was determined by filtering the fermentation broth through pre-weighed filter paper, drying at $105^{\circ} \mathrm{C}$ overnight and weighing.

For intracellular activity measurement, biofilm or mycelial biomass was washed three times with citrate buffer $50 \mathrm{mM}$, $\mathrm{pH} 4.5$, and kept frozen before milling in a mortar with liquid nitrogen. Powdered biomass was resuspended in buffer acetate $50 \mathrm{mM}, \mathrm{pH} 4.8$, and centrifuged at 10000 rpm for $5 \mathrm{~min}$. The supernatant was collected and kept frozen until analysis.

Cellulase as filter paper activity (FPA), endoglucanase (ENG) and xylanase (XYL) were measured from the fermentation broth as previously reported (Dueñas et al. 1995). One international unit (IU) of enzyme activity was defined as the amount of enzyme that releases $1 \mu \mathrm{mol}$ product per min (glucose equivalents for FPA and ENG and xylose equivalents for XYL). Soluble protein and lactose in the fermentation broth were determined by the standard
Lowry and 3, 5-dinitrosalicylic acid methods, respectively.

\section{RESULTS AND DISCUSSION}

The effect of water activity on Aspergillus niger biofilm fermentation and enzyme production was studied by using ethylene glycol as water activity depressor. The spore adhesion process was not altered by $20 \%$ ethylene glycol $\left(\mathrm{a}_{\mathrm{w}}=0.942\right)$ as it can be seen in Figure 1. However, both biofilm and free submerged growth were depressed at high ethylene glycol concentrations. Gervais et al. (1988) found that spore germination is strongly affected by the nature of the water depressor. Also, at high ethylene glycol concentration hyphal turgor is negatively affected and gummy materials are secreted (Figure 1). Low spore germination may explain the low biomass attained at low $\mathrm{a}_{\mathrm{w}}$ (see below).

Comparative time course profiles of fermentation under normal and water stress conditions are depicted in Figure 2. Due to the inoculation process used for biofilm cultures neither freely floating mycelium nor sloughing were observed (Papagianni et al. 2002; Papagianni and Mattey,
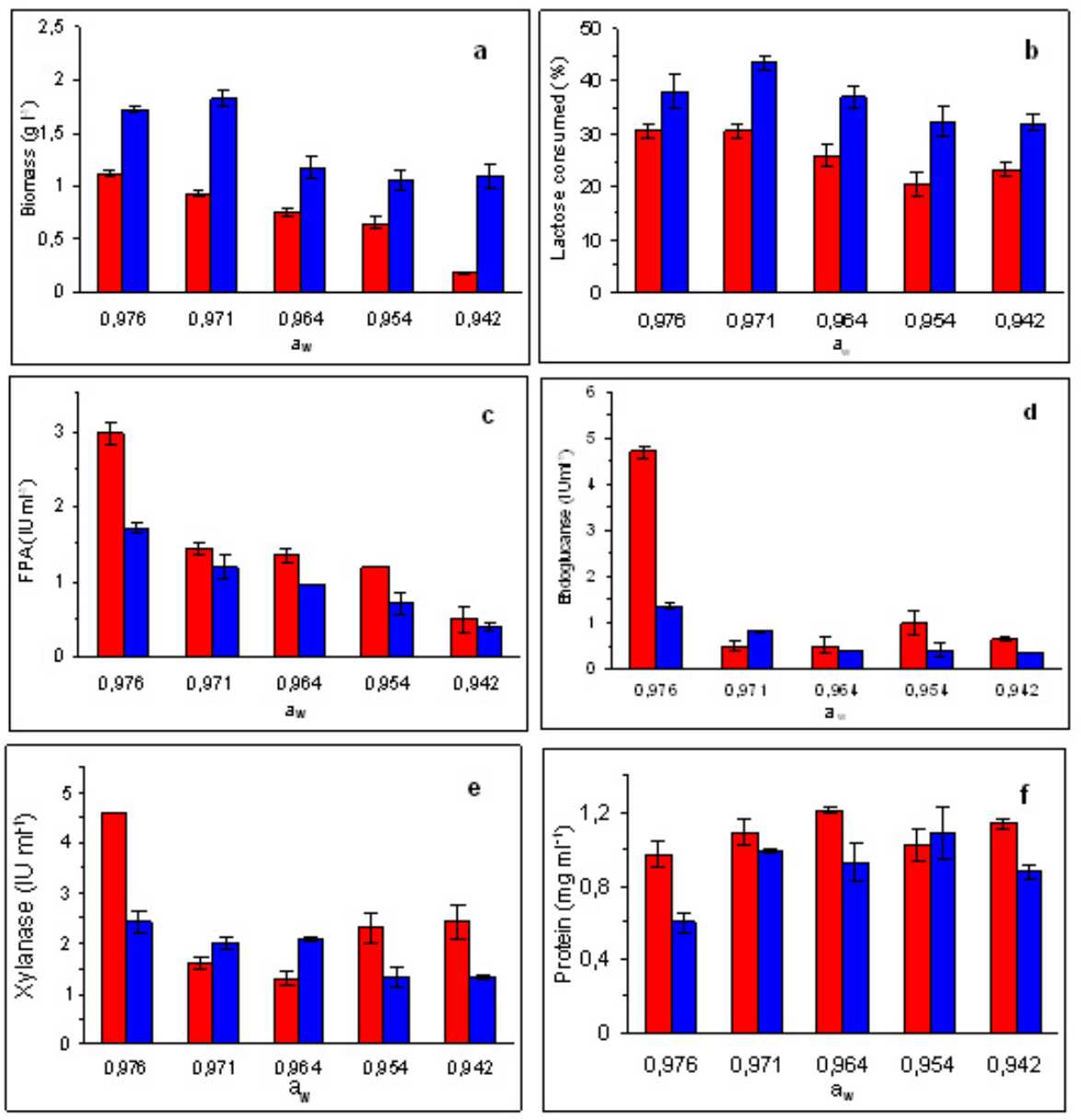

Figure 3. Comparison of fermentation variables of Aspergillus niger biofilm culture (red bars) and submerged culture (blue bars) at different water activity levels. The error bars on the graphs represent two replicate samples. 
2004). Under normal water activity, SF produced more biomass $\left(3.05 \mathrm{~g} \mathrm{l}^{-1}\right)$ than $\mathrm{BF}\left(1.6 \mathrm{~g} \mathrm{l}^{-1}\right)$ as previously found (Gutiérrez-Correa and Villena, 2003) (Figure 2a, b). On the other hand, depression of water activity by ethylene glycol negatively affected the growth of both culture systems, being $\mathrm{BF}$ the most $\left(1.1 \mathrm{~g} \mathrm{l}^{-1}\right.$ and $0.18 \mathrm{~g} \mathrm{l}^{-1}$ for SF and BF, respectively). Low water activity levels decrease growth due to several mechanisms, among them mass transfer of water and solutes across the cell membranes may be of special importance since it would increase the maintenance energy expenditure by the fungus (Francis et al. 2002) as well as the decrease of turgor pressure in the hyphae, which has a great importance on fungal growth (Gervais and Molin, 2003).

Maximal FPA, ENG and XYL production activities were much higher in $\mathrm{BF}\left(2.96,4.7\right.$ and $4.61 \mathrm{IU} \mathrm{ml}^{-1}$, respectively) than in SF (1.71, 1.34 and $2.45 \mathrm{IU} \mathrm{ml}^{-1}$, respectively) (Figure $2 \mathrm{c}, \mathrm{d}, \mathrm{e}$ ), which it is consistent with production yields reported for most of the surface adhesion fermentation processes (Gutiérrez-Correa and Villena, 2003; Viniegra-González et al. 2003; Hölker et al. 2004). This difference cannot be ascribed to the biomass generated in both systems as it was concluded by Díaz-Godínez et al.
(2001) who suggested that increases in exopectinase production by SSF system were related to better fungal growth but not to higher productivity of the enzyme. Also, there was not a significant difference in soluble protein production between both culture systems (Figure 2f). Addition of ethylene glycol decreased maximum FPA, ENG and XYL activities in both SF (0.6, 0.7 and $1.5 \mathrm{IU}$ $\mathrm{ml}^{-1}$, respectively) and $\mathrm{BF}\left(1.2,1.1\right.$ and $2.4 \mathrm{IU} \mathrm{ml}^{-1}$, respectively) but it increased soluble protein production, being higher in biofilm cultures. The reason for the increase in soluble protein production found in low water activity cultures is not understood and the opposite was found for ethylene glycol depressed SSF cultures of A. niger for exopectinase production (Acuña-Argüelles et al. 1994).

Comparison of fermentation variables at $72 \mathrm{hrs}$ of fermentation between SF and biofilm cultures at different ethylene glycol levels are depicted in Figure 3. Biomass and lactose consumption were continuously decreased as ethylene glycol concentration was increased. As stated above, it seems that lactose consumption was hampered by mass transfer limitations due to a decrease in solute diffusion (Gervais and Molin, 2003). Thus growth could be negatively affected due to low carbon-energy availability
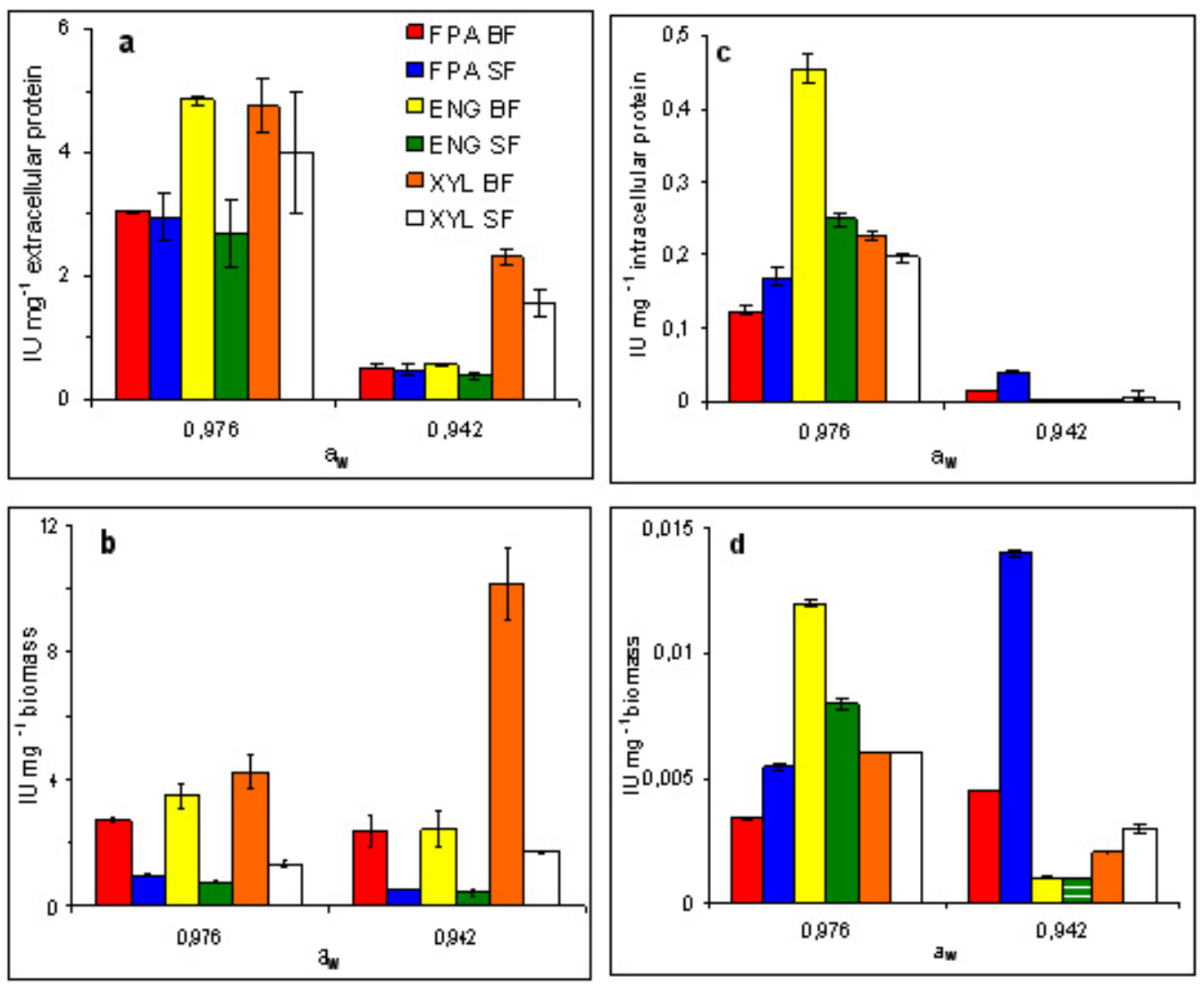

Figure 4. Comparison of extracellular (a, b) and intracellular (c, d) cellulolytic enzyme specific activities attained by Aspergillus niger biofilm (BF) and submerged (SF) cultures at $0 \%\left(a_{w}=0.976\right)$ and $20 \%\left(a_{w}=0.942\right)$ ethylene glycol. The error bars on the graphs represent two replicate samples. 
since the fungus had to spend more energy for membrane transport, and synthesis of compatible solutes (Ruijter et al. 2004). As a weakly chaotropic compound, ethylene glycol can freely traverse the cell membrane and it may not affect hyphal turgor at low concentrations $(5 \%$ to $10 \%)$ but at higher concentrations (above 10\%) it will cause a water stress with general adverse effects on cellular macromolecules (Hallsworth et al. 2003). Also, biomass yields $\left(\mathrm{Y}_{\mathrm{x} / \mathrm{S}}\right)$ in both $\mathrm{SF}$ and $\mathrm{BF}$ systems decreased linearly almost at the same rate as ethylene glycol concentration increased $\left(\mathrm{y}=-0.0408 \mathrm{x}+0.4675, \mathrm{R}^{2}=0.923\right.$, and $\mathrm{y}=$ $-0.039 \mathrm{x}+0.3839, \mathrm{R}^{2}=0.554$, respectively). The low coefficient of correlation between biofilm $\mathrm{Y}_{\mathrm{x} / \mathrm{S}}$ and ethylene glycol concentration may indicate that water stress in this type of culture is stronger than in submerged cultures, possible due to the participation of matrix potential in addition to osmotic potential in the former culture because of the presence of cloth and the biofilm structure itself (Gervais and Molin, 2003).

Enzyme production related to ethylene glycol concentration by $\mathrm{SF}$ and $\mathrm{BF}$ are presented in Figure 3. As it can be seen, all tested enzyme activities strongly decreased in both culture systems although biofilm cultures generally produced more. In submerged cultures the decrease of FPA, ENG and XYL activities was linearly correlated with the increase of water depressor concentration $\left(\mathrm{R}^{2}=0.978\right.$, 0.831 and 0.841 , respectively), indicating a clear direct negative effect of water stress on fungal physiology (Acuña-Argüelles et al. 1994; Díaz-Godínez et al. 2001). However, in biofilm cultures more complex phenomena may be implicated since the decrease of FPA, ENG and XYL activities due to increasing amounts of ethylene glycol follows different patterns. On the other hand, extracellular protein production increased at high water depressor concentrations in both culture systems contrary to the results obtained for exopectinase production in SSF and SF cultures (Acuña-Argüelles et al. 1994; Díaz-Godínez et al. 2001). The reason for this finding is not clear but it may be related to some type of defence mechanism. Hallsworth et al. (2003) have found that induced water stress resulted mostly in the upregulation of proteins involved in stabilization of biological macromolecules and membrane structure. Extracellular and intracellular enzyme specific activities expressed as both IU per mg extracellular or intracellular protein and IU per mg biomass are depicted in Figure 4. Although all specific activities dropped at high ethylene glycol concentration, those related to biomass had the lowest decrease. It is worth mentioning that biofilm XYL extracellular specific activity per biomass increased more than two fold (from 4.2 to $10.2 \mathrm{IU} \mathrm{mg}^{-1}$ biomass). It has been considered that in A. niger both cellulases and xylanases are members of the same regulatory pathway under the control of the transcriptional activator XlnR (van Peij et al. 1998). However, this does not seem to be the case in biofilm cultures under severe water stress and other molecular mechanisms may be involved. On the other hand, the intracellular activity of all enzymes evaluated did not contribute significantly to the overall enzyme activities
(Figure $4 \mathrm{c}, \mathrm{d}$ ) in all $\mathrm{a}_{\mathrm{w}}$ levels tested. Although Kredics et al. (2000) found that enzymatic activities of Trichoderma harzianum and the amount of enzyme secretion (expressed as relative activity) depend on the water potential (or water activity), it is not clear whether the decrease of relative enzymatic activities is directly related to a secretion limitation. According to our results it seems possible that the low water activity affects enzyme biosynthesis rather than their secretion.

In summary, it has been found that biofilm fermentation produces higher cellulolytic enzyme yields than submerged fermentation at lower biomass yields suggesting differential gene expression mechanisms related to cell adhesion (Gutiérrez-Correa and Villena, 2003). Contrary to the findings on SSF, biofilm fermentation can better resist water stress and a differential regulation of xylanase is evident under this condition. Further work is being conducted to clarify some common molecular mechanisms involved in surface adhesion fermentation.

\section{ACKNOWLEDGMENTS}

The authors wish to thank Dr. Robert P. Tengerdy (Colorado State University) for his helpful comments, CERTINTEX (Lima, Perú) for the use of its SEM facilities, and Mr. Gianangelo Nava (CERTINTEX) for his SEM technical assistance.

\section{REFERENCES}

ACUÑA-ARGÜELLES, M.; GUTIÉRREZ-ROJAS, M.; VINIEGRA-GONZÁLEZ, G. and FAVELA-TORRES, E. Effect of water activity on exo-pectinase production by Aspergillus niger $\mathrm{CH} 4$ on solid state fermentation. Biotechnology Letters, January 1994, vol. 16, no. 1, p. 2328.

BHAT, M.K. Cellulases and related enzymes in Biotechnology. Biotechnology Advances, August 2000, vol. 18 , no. 5 , p. $355-383$.

DÍAZ-GODÍNEZ, G.; SORIANO-SANTOS, J.; AUGUR, C. and VINIEGRA-GONZÁLEZ, G. Exopectinases produced by Aspergillus niger in solid-state and submerged fermentation: a comparative study. Journal of Industrial Microbiology and Biotechnology, May 2001, vol. 26, no. 5, p. 271-275.

DUEÑAS, R.; TENGERDY, R.P. and GUTIÉRREZCORREA, M. Cellulase production by mixed fungi in solid-substrate fermentation of bagasse. World Journal of Microbiology and Biotechnology, May 1995, vol. 11, no. 3, p. 333-337.

DUFF, Sheldon J.B. Use of surface-immobilized Trichoderma in batch and fed-batch fermentations. Biotechnology and Bioengineering, March 1988, vol. 31, no. 4, p. 345-348. 
FENCHEL, Tom. Microbial behavior in a heterogeneous world. Science, November 2002, vol. 296, no. 5595, p. 1068-1071.

FIEDUREK, Jan. Production of gluconic acid by immobilized in pumice stones mycelium of Aspergillus niger using unconventional oxygenation of culture. Biotechnology Letters, November 2001, vol. 23, no. 21, p. 1789-1792.

FRANCIS, Febe; SABU, A.; NAMPOOTHIRI, K. Madhavan; SZAKACS, George and PANDEY, Ashok. Synthesis of $\alpha$-amylase by Aspergillus oryzae in solid-state fermentation. Journal of Basic Microbiology, October 2002, vol. 42, no. 5, p. 320-326.

FREEMAN, Amihay and LILLY, Malcolm D. Effect of processing parameters on the feasibility and operational stability of immobilized viable microbial cells. Enzyme and Microbial Technology, October 1998, vol. 23, no. 5, p. 335345.

GERVAIS, Patrick; FASQUEL, Jean-Philippe and MOLIN, Paul. Water relations of fungal spore germination. Applied Microbiology and Biotechnology, December 1988, vol. 29 , no. 6 , p. $586-592$.

GERVAIS, Patrick and MOLIN, Paul. The role of water in solid-state fermentation. Biochemical Engineering Journal, March 2003, vol. 13, no. 2-3, p. 85-101.

GHIGO, Jean-Marc. Are there biofilm-specific physiological pathways beyond a reasonable doubt? Research in Microbiology, January-February 2003, vol. 154 , no. 1 , p. 1-8.

GROBOILLOT, A.; BOADI, D.K.; PONCELET, D. and NEUFELD, R.J. Immobilization of cells for application in the food industry. Critical Reviews in Biotechnology, 1994, vol. 14 , no. 2 , p. $75-107$.

GUTIÉRREZ-CORREA, Marcel and VILLENA, Gretty K. Surface adhesion fermentation: a new fermentation category. Revista Peruana de Biología, 2003, vol. 10, no. 2, p. 113-124.

HALLSWORTH, John E.; HEIM, Sabina and TIMMIS, Kenneth N. Chaotropic solutes cause water stress in Pseudomonas putida. Environmental Microbiology, December 2003, vol. 5, no. 12, p. 1270-1280.

HÖLKER, U.; HÖFER, M. and LENZ, J. Biotechnological advantages of laboratory-scale solid-state fermentation with fungi. Applied Microbiology and Biotechnology, April 2004, vol. 64, no. 2, p. 175-186.

IQBAL, M. and SAEED, A. Novel method for cell immobilization and its application for production of organic acid. Letters in Applied Microbiology, March 2005, vol. 40, no. 3 , p. $178-182$.
KIRK, Ole; BORCHERT, Torben Vedel and FUGLSANG, Claus Crone. Industrial enzyme applications. Current Opinion in Biotechnology, August 2002, vol. 13, no. 4, p. 345-351.

KREDICS, László; ANTAL, Zsuzsanna and MANCZINGER, László. Influence of water potential on growth, enzyme secretion and in vitro enzyme activities of Trichoderma harzianum at different temperatures. Current Microbiology, May 2000, vol. 40, no. 5, p. 310-314.

MA, Hui; SNOOK, Laelie A.; KAMINSKYJ, Susan G.W. and DAHMS, Tanya E.S. Surface ultrastructure and elasticity in growing tips and mature regions of Aspergillus hyphae describe wall maturation. Microbiology, November 2005, vol. 151 , no. 11 , p. 3679-3688.

O'TOOLE, George; KAPLAN, Heidi B. and KOLTER, Roberto. Biofilm formation as microbial development. Annual Review of Microbiology, October 2000, vol. 54, p. 49-79.

PAPAGIANNI, M.; JOSHI, N. and MOO-YOUNG, M. Comparative studies on extracellular protease secretion and glucoamylase production by free and immobilized Aspergillus niger cultures. Journal of Industrial Microbiology and Biotechnology, November 2002, vol. 29, no. 5, p. 259-263.

PAPAGIANNI, Maria and MATTEY, Michael. Physiological aspects of free and immobilized Aspergillus niger cultures producing citric acid under various glucose concentrations. Process Biochemistry, October 2004, vol. 39, no. 12, p. 1963-1970.

PARRA, Roberto; ALDRED, David; ARCHER, David B. and MAGAN, Naresh. Water activity, solute and temperature modify growth spore production of wild type and genetically engineered Aspergillus niger strains. Enzyme and Microbial Technology, August 2004, vol. 35, no. 2-3, p. 232-237.

RUIJTER, George J.G.; VISSER, Jaap and RINZEMA, Arjen. Polyol accumulation by Aspergillus oryzae at low water activity in solid-state fermentation. Microbiology, April 2004, vol. 150, no. 4, p. 1095-1101.

SKOWRONEK, $M$. and FIEDUREK, J. Inulinase biosynthesis using immobilized mycelium of Aspergillus niger. Enzyme and Microbial Technology, January 2006, vol. 38 , no. 1-2, p. 162-167.

VAN PEIJ, Noël N.M.E.; GIELKENS, Marco M.C.; DE VRIES, Ronald P.; VISSER, Jaap and DE GRAAFF, Leo $\mathrm{H}$. The transcriptional activator $\mathrm{X} \operatorname{lnR}$ regulates both xylanolytic and endoglucanase gene expression in Aspergillus niger. Applied and Environmental Microbiology, October 1998, vol. 64, no. 10, p. 3615-3619. 
VILLENA, G.K.; MORENO, P. and GUTIÉRREZCORREA, M. Cellulase production by fungal biofilms on polyester cloth. Agro-food-Industry Hi-Tech, JanuaryFebruary 2001, vol. 12, no. 1, p. 32-35.

VINIEGRA-GONZÁLEZ, Gustavo; FAVELA-TORRES, Ernesto; AGUILAR, Cristóbal Noé; ROMERO-GÓMEZ, Sergio de Jesús; DÍAZ-GODÍNEZ, Gerardo and AUGUR, Christopher. Advantages of fungal enzyme production in solid state over liquid fermentation systems. Biochemical Engineering Journal, March 2003, vol. 13, no. 2-3, p. 157167.

WU, Juan; XIAO, Ya-Zhong and YU, Han-Qing. Degradation of lignin in pulp mill wastewaters by white-rot fungi on biofilm. Bioresource Technology, August 2005, vol. 96 , no. 12 , p. 1357-1363.

YANG, Xuehao; WANG, Bingwu; CUI, Fengnan and TAN, Tianwei. Production of lipase by repeated batch fermentation with immobilized Rhizopus arrhizus. Process Biochemistry, May 2005, vol. 40, no. 6, p. 2095-2103. 